Heta G, Ramadani L, Rashiti N, Bekolli L, Shabani E. Application of bioelectric impedance in the assessment of body components to active and pasiv athletes. Journal of Education, Health and Sport. 2020;10(2):133-139. eISSN 2391-8306. DOI http://dx.doi.org/10.12775/JEHS.2020.10.02.018

https://apcz.umk.pl/czasopisma/index.php/JEHS/article/view/JEHS.2020.10.02.018 https://zenodo.org/record/3686281

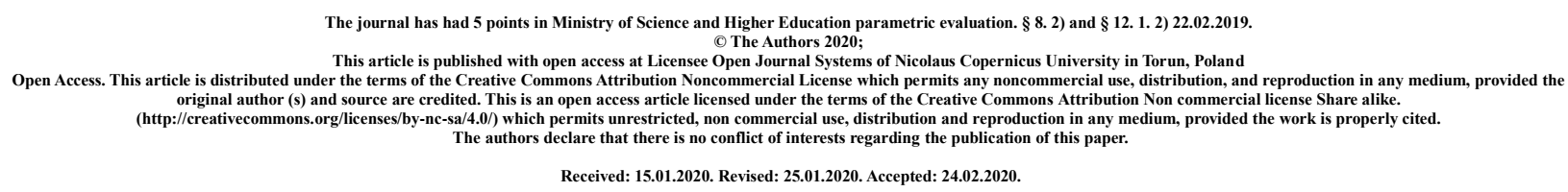

\title{
Application of bioelectric impedance in the assessment of body components to active and pasiv athletes
}

\author{
Heta $\mathbf{G}^{1}$, Ramadani $\mathrm{L}^{2}$, Rashiti $\mathbf{N}^{3}$, Bekolli L ${ }^{4}$, Shabani $\mathrm{E}^{4}$ \\ Physical Education and Sport University of Prishtin - Kosova
}

\begin{abstract}
Assessment of body composition is of particular importance to active athletes, in determining the optimal body mass, especially in controlling the effect of the training process. The purpose of this paper is the confirmation of the goal between active athletes and passive athletes in bodily constituents using the bioelectrical resistance method (BIA). This research has included 50 athletes of 4 complex poly structural sports and 50 passive athletes (former athletes) of these sports; the sample has included a total of 100 tested athletes. The sample of variables from the "TANITA" apparatus (as a bioelectric resistance method (BIA)) is consisted of 10 variables. The basic statistical and asymmetric parameters were applied for the processing of results as well as T-test analysis for independent groups. The results of this research show that significant statistical differences have been earned in the arithmetic averages between active athletes and passive athlete to most of the variables of bodily constituents, especially in adipose tissue variables $p<0.01$. According to the results of this research, it is recommended to use the same method in order to compare the body composition to athletes of various sports.
\end{abstract}

Keywords: Athlete, bioelectrical resistance, bodily constituents, T-test 


\section{Introduction}

In recent decades the importance of physical activity is increasingly emphasized as a very important element for human health. Above all, physical activity affects the prevention and reduction of obesity, cardiovascular and respiratory diseases, and many other diseases, which make us think and act that sporting activity to integrate into everyday life as a natural and indispensable necessity for all people. Physical activity has a strong positive effect on human health, especially the pathogenesis of diseases, which comprise the metabolic syndrome (insulin resistance, type 2 diabetes, hyperlipidemia, hypertension and overweight). There are strong arguments showing that physical activity enhances functional ability and quality of life (Vuori, I. 2004).

There are several reasons that cause overweight ( obesity). One of them may be due to certain hormonal or metabolic disorders (Mustajbegović et al., 2018). However, first of all, obesity is a result of lack of physical activity and inadequate diet (Guyton and Hall, 2008). That is, if the body regularly consumes more calories than it can consume, such calories from food will be converted into excess weight in the form of stored fat. Most people, to avoid being overweight, are subjected to a grueling diet (hunger), which in most cases is associated with many health consequences. As a result of hunger, in addition to loss of sedation, it can also result in loss of muscle tissue which helps to consume excess fat (Findak et al., 1996).

The very best way to achieve your desired goal is regular physical activity. With exercise the stored energy reserves as fat are consumed, and the loss of muscle protein is avoided (Malcko and Rađo, 2006). For this reason, energy for work is not only derived from carbohydrates but also from fats. Persons engaged in physical activity increase the ability to use fat as a source of energy and reduce the risk of various diseases such as diabetes. In order to remove or lose excess fat (Heimer et al., 2004) (Heimer et al., 2004) it is suggested that two types of training should be combined, aerobic and anaerobic training. Nowadays it is increasingly being proven that sports activity is one of the main factors affecting the reduction of body weight and improving the quality of life. Therefore, modern devices are used to determine body mass, which provide more accurate and rapid information on the status of body mass in order to program physical activities. Subcutaneous fat belongs to the components of the human body that can be affected during life. Everyone with this anthropological characteristic can and should associate it with various physical sports activities and food. Adjusting this feature will not only apply it to food, especially with rapid weight loss. Because it is not just about reducing overweight, but also about the normal functioning of the whole organism, which cannot be achieved by diet alone (Findak et al., 1996). In terms of physical culture, body composition is usually seen as a two-component model, consisting of: a) non-fat body mass, and b) body fat mass. This division allows us to calculate the optimal weight (Mišigoj-Durand, M. 1997), which gives us guidance on future treatments, both sports activities and diets.

\section{Purpose of the work}

The problem of this study is the analysis of some parameters of body composition of athletes of different sports and athletes who have previously been involved in sports activities. The purpose of this work is to confirm the difference between active and passive athletes in body composition. 


\section{Working Methods}

The population surveyed for this work is defined as the population of athletes of the four complex structural sport disciplines who have previously played in these sports. The research involved 50 athletes from four complex structural sports and 50 passive athletes (former athletes) of these sports, the total sample included 100 tested. Body height (BHE) is measured for body parameters and body weight (BWE), body fat (BFA), body mass index (BMI), daily caloric intake (DCI), metabolic age (MAG), total water (TBWA), Fat Level (FAL), Bone Mass (BMA) are obtained by applying apparatus for measuring body components, measurement of firm "TANITA" model BC-601. This latest method of measuring body components, the bioelectric impedance (BIA) method, is based on the knowledge that electrical power passes rapidly through tissues that have a greater amount of water in their composition. Since the fatty tissue in its composition has less water, the body's resistance to current disturbance is consistent with the amount of tissue fat in the body. Therefore, electrical resistance is the general index of body fat and is based on different formulas. Descriptive statistical analyses as well as t-test for independent groups were used to process the results.

\section{Results and discussion}

Table 1 shows the basic statistical parameters, arithmetic mean values, minimum score, maximum score, standard deviation, distribution parameters, or asymmetry (Skewness) and extension of the curve (Kurtosis) distribution of body composition variables to non-active and active athletes. Most Skewness and Kurtosis scores on inactive athletes move from a distance between 1 and -1, indicating a normal distribution of results. Greater asymmetry on the right compared to the normal distribution, with positive signs of asymmetric coefficients, is observed at the Metabolic Age (MEAG) Skewness $=1.86$ and the Visceral Fat Level (VFAT) Skewness $=1.482$. The increased value of the asymmetry test (Skewness) indicates the length of the distribution at the highest values indicating that most of the values obtained in these two variables are at the lowest levels. The other positive values of the asymmetric coefficients show a small to medium curvature to the right, while the other variables with negative values of the asymmetry coefficients show a small to medium curve to the left. For active sports, most Skewness and Kurtosis scores move from a distance between 1 and -1 and indicate that most scores have normal distribution. The largest asymmetry on the right compared to the normal distribution, showing positive signs of asymmetric coefficients, is observed to be Metabolic Age Variable (MEAG) Skewness = 1.41, Visceral Fat Level (VFAT) Skewness = 2.12 and Daily Calorie Intake (DCI) Skewness $=1.42$. The increased value of the asymmetry test (Skewness) indicates the length of distribution at the highest values indicating that most of the values obtained in these three variables are at the lowest levels. The other positive values of the asymmetric coefficients indicate a small to medium curvature to the right. It is important to note that all Skewness values for active athletes are positive (epicuristic), that is, all values of the applied variables match the lower ones. 
Table 1. Basic statistical parameters and asymmetry of non-athletic and athletic body composition

\begin{tabular}{|l|r|r|r|r|r|r|r|r|r|}
\hline & \multicolumn{4}{|c|}{ Sports m no active } & \multicolumn{5}{|c|}{ Sports m active } \\
\hline Variables & $\mathrm{N}$ & \multicolumn{1}{|c|}{ Mean } & Std. Dev & Skew & Kurt & \multicolumn{1}{c|}{ Mean } & Std. Dev & Skew & Kurt \\
\hline CAAG & 50 & 32.520 & 2.873 & .409 & -.874 & 23.220 & 2.112 & .627 & -.724 \\
\hline HEIG & 50 & 179.960 & 7.711 & .582 & -.191 & 180.760 & 7.807 & .424 & -.010 \\
\hline WEIG & 50 & 75.620 & 10.047 & -.475 & -.711 & 74.112 & 10.433 & .587 & 1.145 \\
\hline BOFA & 50 & 15.184 & 3.816 & .088 & -.157 & 13.880 & 2.474 & .131 & -.917 \\
\hline MUMA & 50 & 60.830 & 7.771 & -.193 & -1.040 & 60.538 & 7.971 & .382 & .008 \\
\hline BOMA & 50 & 3.164 & .424 & -.739 & .442 & 3.172 & .381 & .358 & -.125 \\
\hline BMI & 50 & 23.278 & 2.382 & -.194 & .646 & 22.590 & 2.071 & .733 & 1.707 \\
\hline DCI & 50 & 3439.200 & 608.376 & -.150 & -.320 & 3423.860 & 509.628 & 1.427 & 1.463 \\
\hline MEAG & 50 & 16.360 & 6.498 & 1.863 & 2.453 & 13.600 & 2.672 & 1.418 & .423 \\
\hline TBWA & 50 & 62.138 & 4.541 & .868 & .613 & 64.152 & 3.596 & .333 & -.520 \\
\hline VFAT & 50 & 2.140 & 1.340 & 1.482 & 2.102 & 1.400 & .755 & 2.126 & 4.346 \\
\hline
\end{tabular}

The correlation coefficients of body components of inactive athletes and active athletes are presented in Table 2. This table shows that the cross-diagonal correlation coefficients are the non-athlete and sub-diagonal correlation coefficients with the athletes. The results obtained show that there is a high correlation between most of the variables of body composition. Calendar age (CAAG) indicates that this variable is related to body fat (BOFA), which explains that body fat (BOFA) increases with number of years of life, increases body mass index (BMI), metabolic age (MEAG), visceral fat level (VFAT) while decreasing total body water (TBWA). Body height (HEIG) stands in correlation with variables, Body weight (WEIG), Muscle Mass (MUMA), Bone Mass (BOMA), Daily Calorie Intake (DCI), that is, it is not correlated with any variables that measure body fat. Body weight (WEIG), stands in correlation with all the variables of body composition. Body fat (BOFA) is correlated with variables, Calendar age (CAAG), Body weight (WEIG), Body mass index (BMI), Metabolic age (MEAG), Total body water (TBWA), Visceral fat level (VFAT). Muscle Mass (MUMA) does not correlate with the variables that measure body fat.

Bone mass (BOMA) does not correlate with four variables, Calendar age (CAAG), and variables that measure body fat content. The body mass index (BMI) is related to all body composition variables. Daily Calorie Intake (DCI) is correlated with Body Height (HEIG), Body Weight (WEIG), Muscle Mass (MUMA), Bone Mass (BOMA), Body Mass Index (BMI). Metabolic age (MEAG) is correlated with Calendar age (CAAG), Body weight (WEIG), Body fat (BOFA), Daily calorie intake (DCI), Total body water (TBWA) and Visceral fat level (VFAT). Total body water (TBWA) stands in correlation with all the variables of bodily composition. Visceral fat level (VFAT) does not stay in correlation only with variable body height (HEIG). Regarding height correlation, body composition variables are grouped into two groups, the first group consists of Calendar Age (CAAG), body fat (BOFA), metabolic age (MEAG), total body water (TBWA). . , fat level (VFAT). The second group consists of body height (HEIG), body weight (WEIG), muscle mass (MUMA), bone mass (BOMA), body mass index (BMI) and daily calorie intake (DCI). 
Table 2. Intercorrelation between body composition variables, over the diagonal to non-athletes, under diagonal to athletes

\begin{tabular}{|c|c|c|c|c|c|c|c|c|c|c|c|}
\hline & CAAG & HEIG & WEIG & BOFA & MUMA & BOMA & BMI & DCI & MEAG & TBWA & VFAT \\
\hline CAAG & 1 & -.225 & .196 & $.752 * *$ & -.047 & .026 & $.478 * *$ & -.123 & $.522 * *$ & $-.680 * *$ & $.558 * *$ \\
\hline HEIG & .094 & 1 & $.696 * *$ & -.191 & $.805 * *$ & $.733 * *$ & .062 & $.825 * *$ & -.174 & -.131 & .030 \\
\hline WEIG & $.343 *$ & $.771 * *$ & 1 & $.342 *$ & $.943 * *$ & $.932 * *$ & $.758^{* *}$ & $.849 * *$ & $.337 *$ & $-.519 * *$ & $.517 * *$ \\
\hline BOFA & $.916 * *$ & .061 & $.398 * *$ & 1 & .014 & .098 & $.645^{* *}$ & -.056 & $.814 * *$ & $-.880 * *$ & $.740 * *$ \\
\hline MUMA & .167 & $.814 * *$ & $.978 * *$ & .202 & 1 & $.967 * *$ & $.583 * *$ & $.926 * *$ & .051 & -.251 & .270 \\
\hline BOMA & .175 & $.810 * *$ & $.976 * *$ & .204 & $.997 * *$ & 1 & $.637 * *$ & $.904 * *$ & .052 & $-.348 *$ & .260 \\
\hline BMI & $.442 * *$ & .253 & $.808 * *$ & $.554 * *$ & $.737 * *$ & $.736^{* *}$ & 1 & $.450 * *$ & $.624 * *$ & $-.607 * *$ & $.693 * *$ \\
\hline DCI & .193 & $765 * *$ & $948 * *$ & 327. & $.958 * *$ & $.958 * *$ & $.727 * *$ & 1 & -.001 & -.168 & .206 \\
\hline MEAG & $.638 * *$ & .009 & $.375^{* *}$ & $.837 * *$ & .205 & .185 & $.566 * *$ & $.322 *$ & 1 & $-.699 * *$ & $.920 * *$ \\
\hline TBWA & $-.746 * *$ & $-.332 *$ & $-.700 * *$ & $-.808 * *$ & $-.573 * *$ & $-.575 * *$ & $-.772 * *$ & -.216 & $-.664 * *$ & 1 & $-.732 * *$ \\
\hline VFAT & $.557 * *$ & .065 & $.539 * *$ & $.748 * *$ & $.394 * *$ & $.380 * *$ & $.745^{* *}$ & $.384 * *$ & $.889 * *$ & $-.641 * *$ & 1 \\
\hline \multicolumn{12}{|c|}{ *. Correlation is significant at the 0.05 level (2-tailed). } \\
\hline
\end{tabular}

Table 3 shows the differences between active athletes and inactive athletes in body composition. The obtained results show that differences in body composition variables have been gained. But important statistical differences were gained in the variables: Calendar age (CAAG) sig $=0,000$ and $\mathrm{p}<0,000$, which was also expected because inactive athletes are older than active athletes, then to Body Fat variables (BOFA) sig $=0.045$ and $\mathrm{p}<0.05$, Metabolic age $(\mathrm{MEAG}) \mathrm{sig}=0.007$ and $\mathrm{p}$ $<0.01$, Total body water (TBWA) sig $=0.016$ and $p<0.05,=0.001$ and $p<0.01$. There were no significant statistical differences in the variables: Body height (HEIG) sig $=0.607$ and $p>0.01$. Body weight (WEIG) sig $=0.463$ and $\mathrm{p}>0.01$., Muscle mass (MUMA) sig $=0.853$ and $\mathrm{p}>0.01$., Bone mass (BOMA) sig $=0.921$ and $p>0.01$., Body Mass Index (BMI) sig $=0.127$ and p $>0.01$., Daily Calorie Intake (DCI) sig $=0.892$ and $\mathrm{p}>0.01$. A higher level of motor and functional abilities for active athletes compared to inactive athletes can be attributed to endogenous and largely exogenous factors, namely the processes of transformation in sports clubs in relation to inactive athletes. It is known that active athlete training is characterized by a gradual increase in load on the upper functional-motor cap, which has enabled super-compensation processes for each active athlete. This is one of the basic functional reactions of the organism, based on the organism's adaptation processes. For active athletes training sessions resulting in loss of body fat, increasing metabolism manifested by compensating the lost energy during exercise. As physical activity declines, the ratio between calorie intake and consumption decreases. This is also manifested by the accumulation of adipose tissue that poses a threat to human health.

The results obtained in this paper, which show an increase in fatty mass, which is the leading cause of many diseases, relate to works showing that many diseases are more common in people who are very little or no longer engaged in physical activity rather than regular individuals who are physically active (Vuori, 2004). 
Table 3. Difference between active athletes and inactive athletes in body composition

\begin{tabular}{|l|r|r|r|r|r|r|r|r|r|}
\hline & \multicolumn{1}{|c|}{$\mathrm{F}$} & Sig. & \multicolumn{1}{c|}{$\mathrm{t}$} & \multicolumn{1}{c|}{ Df } & \multicolumn{1}{c|}{ Sig. } & Mean Diff. & Std. Error Diff. & \multicolumn{1}{l}{ Lower } & \multicolumn{1}{c|}{ Upper } \\
\hline CAAG & 5.287 & .024 & -18.442 & 98 & .000 & -9.3000 & .50429 & -10.3007 & -8.2992 \\
\hline HEIG & .068 & .794 & .515 & 98 & .607 & .8000 & 1.55196 & -2.2798 & 3.8798 \\
\hline WEIG & .428 & .515 & -.736 & 98 & .463 & -1.5080 & 2.04850 & -5.5731 & 2.5571 \\
\hline BOFA & 5.158 & .025 & -2.027 & 98 & .045 & -1.3040 & .64328 & -2.5805 & -.0274 \\
\hline MUMA & .043 & .836 & -.185 & 98 & .853 & -.2920 & 1.57436 & -3.4162 & 2.8322 \\
\hline BOMA & .635 & .428 & .099 & 98 & .921 & .0080 & .08070 & -.1521 & .1681 \\
\hline BMI & .894 & .347 & -1.541 & 98 & .127 & -.688 & .44649 & -1.5740 & .1980 \\
\hline DCI & 1.756 & .188 & -.137 & 98 & .892 & -15.340 & 112.23570 & -238.0682 & -207.3882 \\
\hline MEAG & 12.677 & .001 & -2.777 & 98 & .007 & -2.7600 & .99376 & -4.73208 & -.7879 \\
\hline TBWA & .923 & .339 & 2.458 & 98 & .016 & 2.0140 & .81922 & .3882 & 3.6397 \\
\hline VFAT & 8.673 & .004 & -3.401 & 98 & .001 & -.7400 & .21761 & -1.1718 & -.3081 \\
\hline
\end{tabular}

\section{Conclusion}

In all sports or physical activities organized for competitive purposes, the assessment of body composition is of particular importance in determining optimal body mass, optimizing nutrition, controlling sport performance, and controlling the effect of the training process. For active athletes physical sports activity is and remains a biological stimulus necessary to maintain the functions of organs and normal functioning of the body by maintaining body homeostasis. Many adaptive changes due to physical activity also reduce the risk of certain diseases such as excessive body weight. Physical inactivity such as the lack of a biological stimulus has completely opposite effects and increases the risk of a number of diseases due to being overweight, especially the increase in body fat. The results obtained in this paper show that physical activity decreases from the moment an active athlete decides to be inactive in any sport, and thus increases body fat in the inactive athlete's body. 


\section{References}

1.Vuori, I. (2004). Tjelesna neaktivnost je uzrok, e tjelesna aktivnost lijek za glavne javnozdrevsvene problem. Kinesiology, 36, 2, 123-153.

2.Guyton \& Hall, J.E., 2008. Buku Ajar Fisiologi Kedokteran. Edisi 11. Jakarta : EGC. Pg 10721094.

3.Mustajbegović, J., Milan Milošević, M., Hana Brborović, H. (2018). Medicina rada isporta. Zagreb : Medicinska naklada.

4. Findak, V., Metikoš, D., Mraković, M., Neljak, B., \& Prot, F. (1996). Primjenjena kineziologija u školstvu (Norme). Hrvatski pedagoški-književni zbor [Applied kinesiology in schools (Norms). Croatian pedagogical-literary association]. Zagreb, Croatia: Fakultet za fizičku kulturu Sveučilišta u Zagrebu.

4.Heimer, S., Misigoj-Duraković, M., Ruzić, L., Matković, B., Prskalo, I., Beri, S., . . TonkovićLojović, M. (2004). Fitness level of adult economically active population in the Republic of Croatia estimated by EUROFIT system. Collegium Antropologicum, 28, 223-233.

5.Malacko, J., Rađo, I. (2006). Menadžment ljudskih resursa u sportu. Sarajevo: Fakultet sporta i tjelesnog odgoja.

6.Mišigoj- Duraković, M. (1997). Morfološka antropometrija u dijagnostičkom postupku kod sportaša. U D. Milanović i S. Heimer (ur.), Zbornik radova Mežunarodnog savjetovanja «Dijagnostika treniranosti sportaša»<u sklopu $>6$. Zagrebačkog sajma športa, Zagreb, 1.ožujka 1997 (str.9). Zagreb: Fakultet za $\square$ zičku kulturu Sveučilišta u Zagreb

Correspondence to:

Rashiti Naser, PhD

Physical education and Sport

University of Prishtin - Kosova

Phone: +38349666 619

E-mail: naser.rashiti@uni-pr.edu 